\title{
ட字通路でのすれ違いにおける相手との相互影響によって生じる 判断特性の変化を考慮した歩行者の行動判断モデルの構築*
}

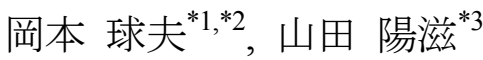 \\ Construction of Decision Model for Determining the Behavior of Pedestrians Encountering at a L-shaped Corner by Considering Dynamics of Judgment Characteristics Caused by Interplays with the Other}

\author{
Tamao OKAMOTO*1,*2 and Yoji YAMADA \\ ${ }^{* 1}$ Graduate School of Engineering, Nagoya University \\ Furo-Cho, Chikusa-ku, Nagoya 464-8603, Japan \\ ${ }^{*}$ Global Manufacturing Division, Panasonic Corporation \\ 2-7, Matsuba-cho, Kadoma 571-8502, Japan
}

In the paper, we construct a decision model for determining the behavior of pedestrians encountering at a L-shaped corner taking into consideration the dynamics of judgment characteristics caused by interplays with each other. First, we formulate parameters that characterize the behavioral judgment of pedestrians according to the model, based on the game theory. Further, we extend the decision model to exhibit dynamic behaviors of changing their judgment characteristics using evolutionary game theory and reinforcement learning. Then, the extended model was experimented to verify the effectiveness by simulation. Based on such a model as to take human judgment characteristics into account, robot navigation control is expected to realize the safe operations even at indoor blind corners that contain a high risk of collision.

Key Words : Safety, Collision Avoidance, Behavioral Judgment Modeling, Game Theory, Reinforcement Learning

\section{1. は じめに}

移動ロボットが人と共存するためには，両者の衝突を回避し、共存系の安全性が確保できることが必須である． 特に, 屋内の曲がり角では死角が存在するため, 衝突による高いリスクが存在する. 兴のため, 学校や病院施設 等における出会い頭の衝突に対する安全対策が, 国や自治体レベルで検討されている(1)(2). 安全対策として, 通路 の角を落したり，ミラーの取り付けなどが実施されているが，いづれも経験に基づいたものである．したがって， 移動ロボットが走行するような未知の想定状況において, 必要とされる安全対策や光の詳細仕樣を事前に検討す ることはできない．これに対し，移動ロボットの衝突対象である歩行者の行動や炎の判断をモデル化したり，シ ミュレーションによって検証することができれば, 新たに移動ロボットを導入する際にも, 安全かつ効率的な屋内 交通の運用を事前に検討し，光の効果も確認することができる．例えば，移動ロボットと歩行者が遭遇する局面 においても，対向する歩行者の行動判断を予測し，彼らとの衝突を回避するための手段を前もつて講じることが 期待できる. として, 光のような検討を経ることによって人共存環境への移動ロボット導入が促進され, 人々が 移動ロボットによるメリットを安心安全に享受できるようになると期待できる .

すれ違う歩行者の衝突回避に向けた行動や判断のモデル化に関する従来の研究では, ポテンシャルエネルギー を用いた回避行動モデルが提案されている ${ }^{(3)}$. また , パーソナルスペース ${ }^{(4)}$ に起因する歩行者間の距離に関する研 究 $^{(5)(6)}$ も盛んに行われており, これを考慮した経路モデル ${ }^{(7)(8)(9)}$ も数多く提案されている. 兴の他にも，セルオ一

\footnotetext{
* 原稿受付 2012 年 11 月 18 日

*1 正員, 名古屋大学 大学院工学研究科 (

*2 正員, パナソニック (株) モノづくり本部（テ571-8502 大阪府門真市松葉町 2-7）

*3 正員, フェロー, 名古屋大学 大学院工学研究科

E-mail: okamoto.tamao@jp.panasonic.com
} 


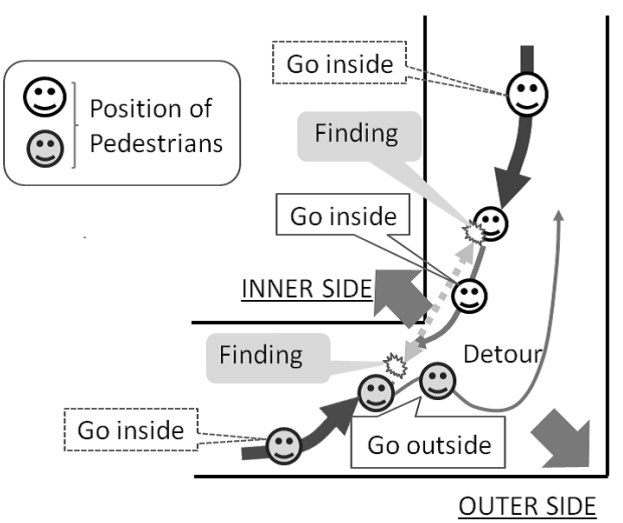

(a) Situation of model

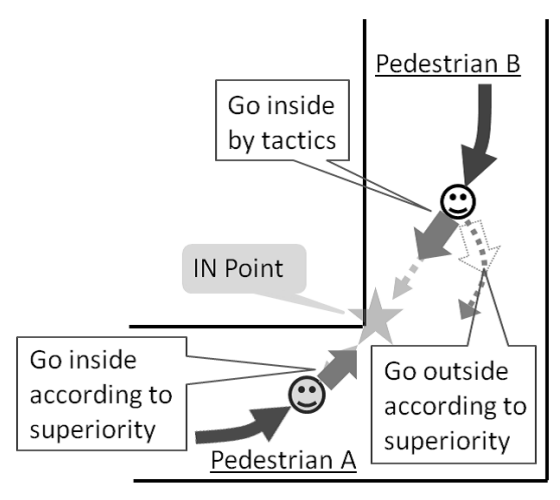

(b) Sample behavior

Fig. 1 L-shaped corner encounter situation with 2 pedestrians' behavioral judgment

トマトンを用いた歩行流モデル ${ }^{(10)}$ などの研究も行われている . これらの研究では, いずれも歩行者の位置関係に よって行動が一意に決定される事を前提としている.

しかし，実際の歩行者の行動は必ずしも双方の位置関係によって一意に決まるものではない，筆者らが行った

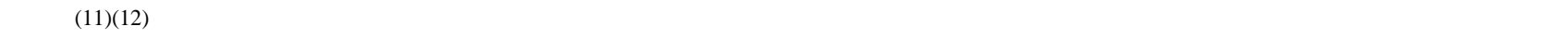
相手の出方によって変化する歩行者の行動を考慮したモデル化に関して , 浅野ら ${ }^{(14)}$ は, 交差する歩行者の「進む」 「止まる」の判断をゲーム理論によってモデル化する提案を行っている．また，筆者らの研究 ${ }^{(12)} て ゙ は ， L$ 字通路で すれ違う歩行者の「最短経路をとる」「回避経路をとる」の判断に関して，ゲーム理論と証拠理論を組み合わせた モデル化を提案している．

以上のようなモデル化により，相手の出方を考慮した行動判断を再現できるようになった．しかし，これらのモ デルでは歩行者の判断特性は一定であり，相手に合わせて判断特性を変化させるダイナミクスは考慮されていな い. 弚こで本論文では，筆者らが提案しているゲーム理論を用いた行動判断モデルをベースとして，歩行者の判 断特性の変化のダイナミクスを考慮したモデルを構筑する . まず, 歩行者の判断特性を示すパラメータの定式化 を行い, 進化ゲーム理論と強化学習を用いて, 相手の行動に応じて判断特性を変化させる動的な行動判断モデル への拡張を行う．乥して，拡張したモデルを用いてシミュレーションを行い，提案モデルの有効性を検証する．

\section{2. 問 題 設 定}

本論文では，モデル化に際して次のような問題設定を行う．図1(a)のような屋内の L 字通路を対象とし，歩行 者同士の 1 対 1 のすれ違いを想定する .このような条件下ですれ違う歩行者は，同図に示すように行動することが 判っている ${ }^{(11)(12)}$. 歩行者は, 死角によって相手が見えない間はコーナーのイン側を通ろうとする . しかし, 死角 から外れて相手を発見すると，衝突をしないようにイン側とアウト側を分け合ってすれ違う. 図 1(b) は，この時 の歩行者が状況に応じてイン側，もしくはアウト側に向うように歩を進めている樣子を示している．通常は，すれ

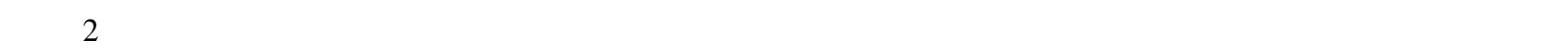
利な状態にある歩行者 B がアウト側の回避経路を通る．しかし，同図の歩行者 B に見られるように，コーナーの インポイントから遠く不利であるにも関わらず，相手がアウト側に譲ることを期待してイン側に向うこともある．

本論文では，死角から外れて相手が見える位置関係になってから，2 人の歩行者の交差が完了するまでの間を 1 回のすれ違いと考え, 产の間で歩を進める際にイン側, アウト側のどちらに踏み出すかを決定する判断のモデル 化を行う.ここで, 双方の歩行者は, 足を踏み出す直前に, 弚の時の歩行者の位置関係や, 光れまでの状態遷移に 基づいて判断を行うものと仮定する. 
Table 1 Game Setting (strategy map)

\begin{tabular}{|c|c|c|c|}
\hline & \multicolumn{2}{|c|}{ Pedestrian B } \\
\hline & & Go inside & Go outside \\
\hline \multirow{2}{*}{ 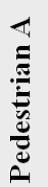 } & $\begin{array}{l}\text { Go } \\
\text { inside }\end{array}$ & $\begin{array}{c}(C a, C b) \\
(1-P a(p), 1-P b(p))\end{array}$ & $\begin{array}{c}(0, A b) \\
(1-P a(p), P b(p))\end{array}$ \\
\hline & $\begin{array}{l}\text { Go } \\
\text { outside }\end{array}$ & $\begin{array}{c}(A a, 0) \\
(P a(p), 1-P b(p))\end{array}$ & $\begin{array}{c}(C a+A a, C b+A b) \\
(P a(p), P b(p))\end{array}$ \\
\hline
\end{tabular}

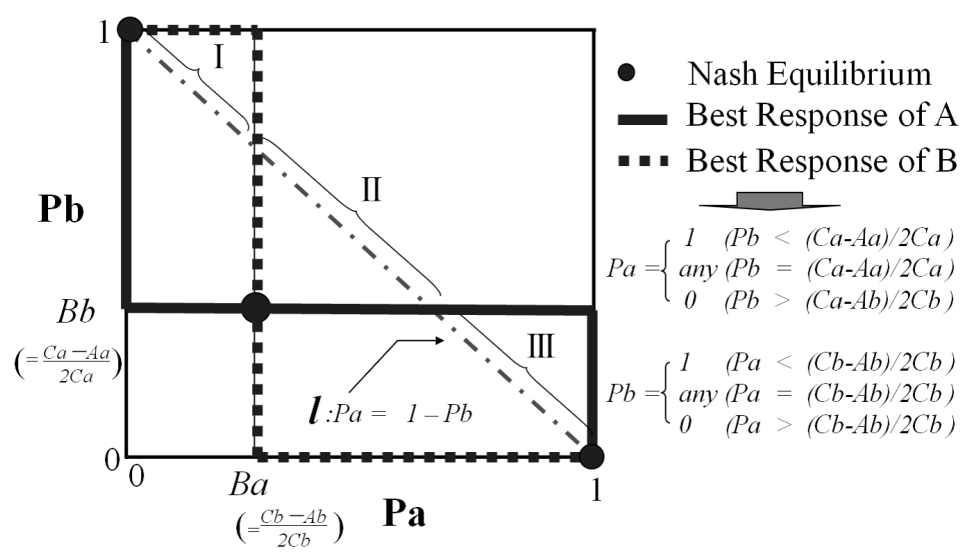

Fig. 2 Best response

3. ゲーム理論を用いた行動判断モデル

\section{$3 \cdot 1$ 行動判断モデル}

筆者が提案するゲーム理論 ${ }^{(15)}$ を用いた行動判断モデル ${ }^{(12)}$ を以下に示す . まず，すれ違う2 人の歩行者 A と B は 遠回りはしたくないが，衝突はさらに避けたいという動機によって行動を決定していると仮定し，表 1 に従った

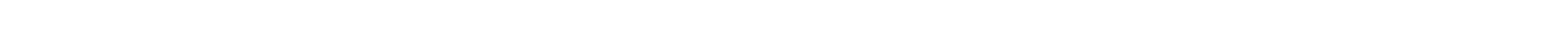
者が同じコースを選択した場合は衝突の可能性が生じるため, 両者に衝突利得 $C a, C b$ がちえらる . また , ア ウト側コースを選択した歩行者は遠回りを強いられるため，回避利得 $A a, A b$ が与えられる．どちらの状態も歩行

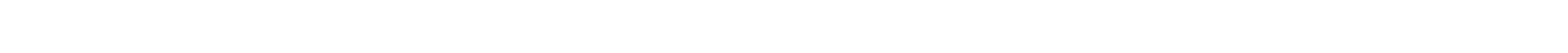
コースの選択確率」を乥れぞれ $P a(p), P b(p)$ とする .ここで，指標 $p$ は歩行者の相対的な位置関係におけるイン

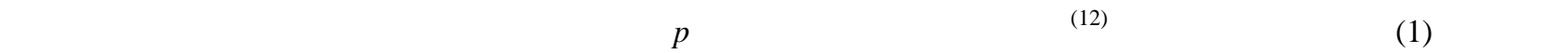
ている(13) .

$$
p=p_{1}+p_{2}
$$

ここで示す優位性 $p$ は, コーナーのイン側に先に到達できる条件を示す $2 つ$ つ指標 $p_{1}, p_{2}$ で構成されている . 光 して，光の $2 つ$ 指標は光れ光れ式 (2)〜 (4) に従って，5段階の数值で与えられるものとする．また，式中の各パ ラメータの関係を図 3 に示す .

$$
\begin{gathered}
p_{i}=\left\{\begin{array}{c}
-2\left(s_{i}<L L_{i}\right) \\
-1\left(L L_{i} \leq s_{i}<L_{i}\right) \\
0\left(L_{i} \leq s_{i} \leq H_{i}\right) \quad i=1,2 \\
1\left(H_{i}<s_{i} \leq H H_{i}\right) \\
2\left(s_{i}>H H_{i}\right)
\end{array}\right. \\
s 1=(W a-W b) * L s / L a b \\
s 2=\operatorname{int}\left(\left(L a+S_{f}\right) / S_{f}\right) / \operatorname{int}\left(\left(L b+S_{f}\right) / S_{f}\right)
\end{gathered}
$$

最初の指標 $p_{1}$ の判断基準となる $s 1$ は,「コーナー内側の壁からの距離」の差を示しており，式 (3) の $W a, W b$ は歩 


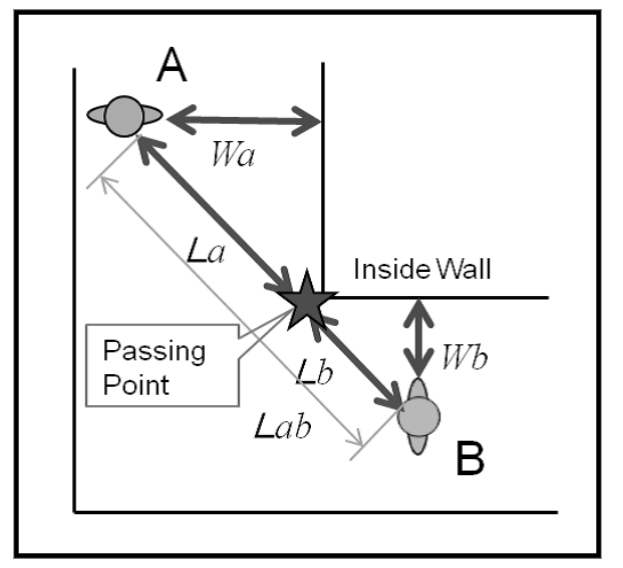

Fig. 3 Evaluation of superiority

行者 A,B の位置からコーナーの内側の壁までの最短距離を示している .さらに $s 1$ では, 歩行者間の距離の基準値 $L s$ を歩行者間の距離 $L a b$ で割ったものを係数として , この「コーナー内側の壁からの距離」の差 $(W a-W b)$ に掛 けることで, 同じ差でも歩行者間の距離が近いほど優位性への影響が大きくなるようにしている．2つ目の指標 $p_{2}$ の判断基準となる $s 2$ は, 「交差予測位置に到達するまでに要する歩数」の比を示している . 式 (4) の $L a, L b$ は歩 行者 A,B の交差予測位置までの距離， $S_{f}$ は歩行者の標準的な歩幅を示している．なお，交差予測位置には，2人 の歩行者の「コーナーによる死角から外れた最初の 1 歩目」となる位置を直線で結び， これを両者の速度比で分

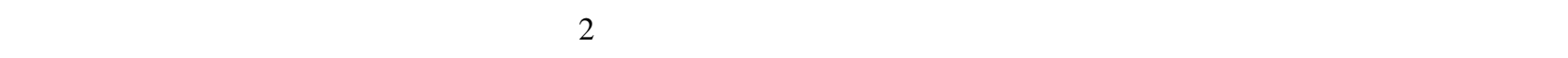
幅に有利」,「少し有利」,「同程度」「「少し不利」,「大幅に不利」程度のおおまかな判断を行っていると考え, 判定 の閾值 $L L_{i} \sim H H_{i}$ によって，弚れ光れ 5 段階評価を行なうものとした .

以上の例のように, $p$ の值が小さいほどコーナーの内側に近く，すれ違い位置に早く到達することができると見 込まれる .すなわち, 優位性において有利であるほど, 歩行者はイン側を選択するため $P a(p), P b(p)$ は小さな值 となり，不利なほど大きな值となる．また，優位性 $p$ は相対的な值であり $P a(p), P b(p)$ も $P a(p)+P b(p)=1$ の 関係を満たすものとする. 光して, 歩行者は期待利得を最大化する合理的判断, すなわち最適反応戦略 ${ }^{(16)}$ に基づ きコースを選択すると仮定する .このゲームの最適反応戦略の閾値 $B a, B b$ は下式 (5)(6) で与えられる.

$$
\begin{aligned}
& B a=(C b-A b) / 2 C b \\
& B b=(C a-A a) / 2 C a
\end{aligned}
$$

求められた $B a, B b$ は, 本モデルにおける行動判断の閾値となる . また , 上式は $K i=A i / C i(i=a, b)$ で与えられる 衝突と回避の 2 つの利得の比率 $K a, K b$ ( = 利得構造) によって式 (7)(8) と書き換えることができる.

$$
\begin{aligned}
& B a=(1-K b) / 2 \\
& B b=(1-K a) / 2
\end{aligned}
$$

図 2 は , このゲームの最適反応戦略をグラフ化したものである .ここで, 両者の戦略実現確率は $P a(p)+P b(p)=1$ の関係より一点鎖線 $l$ 上に限定される . この直線は最適反応戦略の閾值 $B a, B b$ により 3 つの領域 I〜III に分割さ れ，歩行者は光れぞれの領域で次のようなコース選択を行うものとする.

領域 I 優位性の有利不利どおりに A がイン側 , B がアウト側のコースを選択する .

領域 II どちらの歩行者もイン側のコースを選ゔのが合理的であるが，どちらも確実にイン側がとれるとは限ら ないため，結果的に確率的なコース選択が行われる

領域 III 優位性の有利不利どおりに A がアウト側，B がイン側のコースを選択する .

本モデルでは，領域 II において，実際の歩行者同士のすれ違いの際に，多くの事例で特徵的に見られた「相対的 な位置関係において不利であってもあえてイン側コースを進み , 相手がアウト側入譲ることを期待する」駆け引 


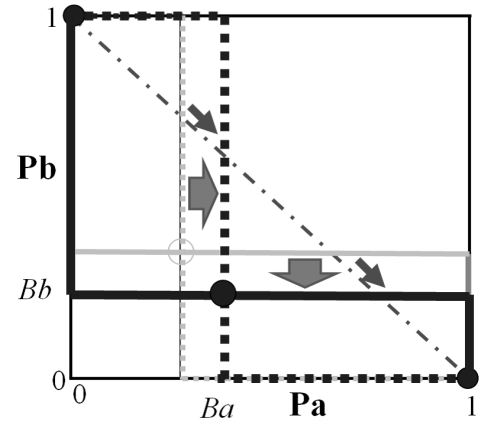

(a) Pushy type

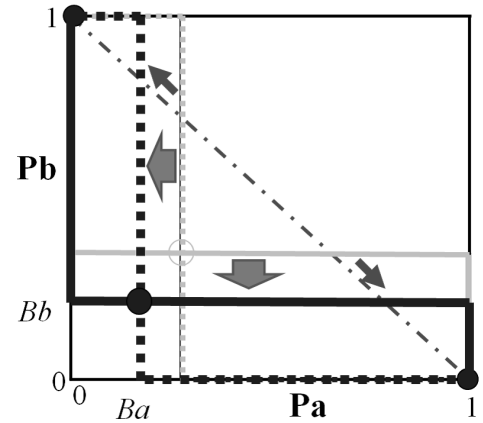

(c) Tactic type

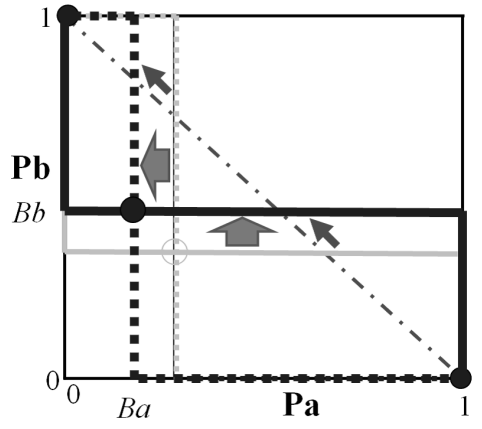

(b) Wimpy type

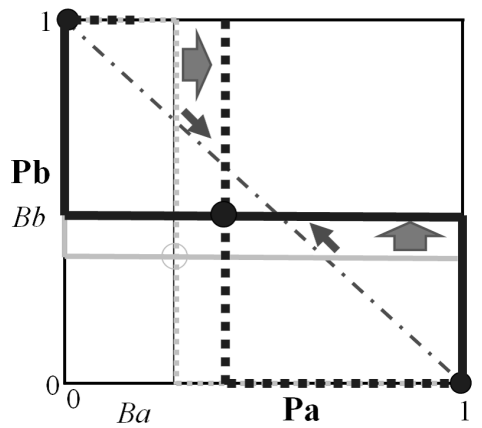

(d) Steady type

Fig. 4 Characteristics of judgment

きの行動を再現する．また，歩行者は相手の利得構造を知っているわけではないため，歩行者は光れ攵れが戦略 表を持ち，自分か想像する「相手の利得構造」を用いて自らの行動を決定するものと考える．

\section{4. 歩行者の性質と判断特性のモデル化}

提案のモデルを用いることで, 単に歩行者の行動判断を再現するだけではなく, 歩行者の性質と判断特性を表 すことができる . 利得構造 $K i$ は衝突利得に対する回避利得の大きさを示しており，小さいほど回避をいとわない， いわゆる「ハト」派の性質を示す . 大きいほど回避を避けるようになり，いわゆる「タカ」派の性質を示す . この ような歩行者の性質を考慮すると，図 4 に示すように領域の幅を変化させることで, 歩行者の判断特性を以下の 4 つに分類することができる．図4(a)のように，領域 I が増え，領域 III が減ると，歩行者 A は相手がアウト側に譲 ると考えて，より積極的にイン側を選択する，いわゆる「強引 (Pushy type)」な判断特性を示す．逆に，図 4(b)の ように，領域 Iが減り，領域 III か増えると，相手がイン側に来ると考えて，自分がアウト側に譲ろうとする，い わゆる「弱気 (Wimpy type)」な判断特性を示す.一方, 図 4(c)のように領域 II の領域か増えると, 活発に駆け引 きを行う，いわゆる「戦略 (Tactic type)」的な判断特性を示す．逆に，図 4(d) のように領域 II の領域が減ると，優 位性に従った行動を取って極力駆け引きは行わない，いわゆる「着実 (Steady type)」な判断特性を示す．

これらの特性を整理すると，図 5 に示す $M_{B}$ と $W_{B}$ が歩行者の判断特性を端的に示す指標であると考えられる． $M_{B}$ は各領域の閾值 $B a, B b$ の中間値であり，領域 I と領域 III の大きさの差で決まる．したがって，この指標が小 さくなれば弱気な判断特性を示すようになり，逆に大きくなれば強引な判断特性を表すと考えられる，一方， $W_{B}$ は領域 II の幅を示す $B a$ と $B b$ の差であり，この指標が大きくなれば駆け引きの領域が広くなり，戦略的な判断特 性を示す。逆に，小さくなれば着実な判断特性を示す .ここで, $M_{B}$ と $W_{B}$ は式 (9)(10) で与えられる .

$$
\begin{aligned}
& M_{B}=((1-B b)+B a) / 2 \\
& W_{B}=(1-B b)-B a
\end{aligned}
$$

式 (7)(8) より，目的とする $M_{B}, W_{B}$ を与える歩行者の利得構造 $K a, K b$ は, 次のように求められる .

$$
\begin{aligned}
& K a=2 M_{B}+W_{B}-1 \\
& K b=-2 M_{B}+W_{B}+1
\end{aligned}
$$




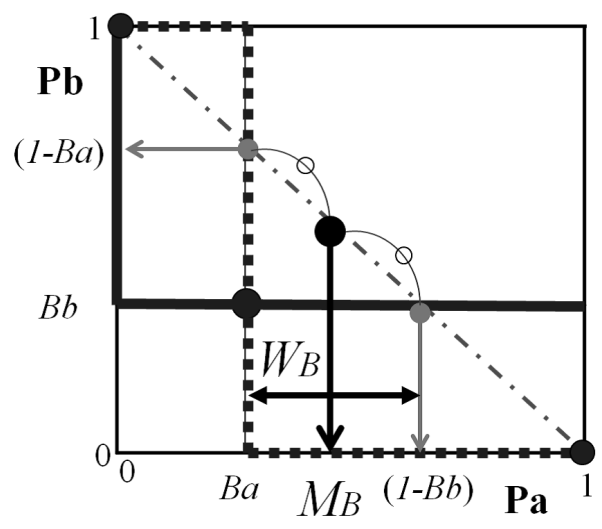

Fig. 5 Indicators of gain structure

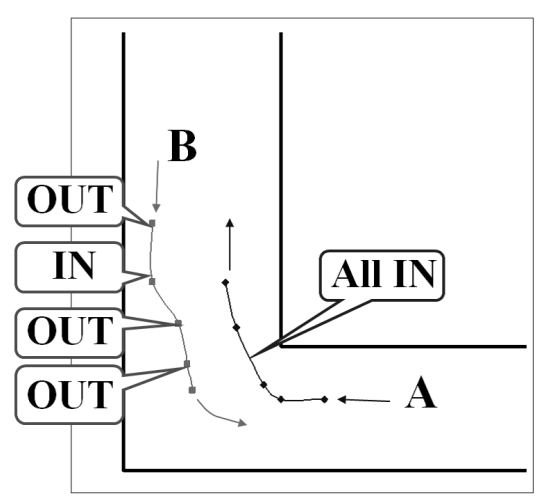

(a) Characteristic behavior (real pedestrian)

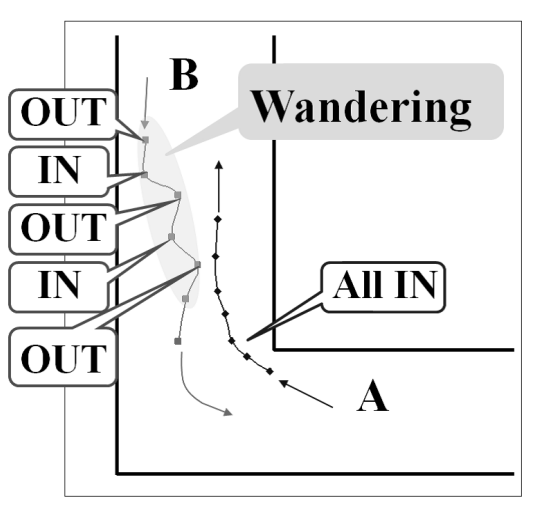

(b) Unnatural behavior (simulation)

Fig. 6 Behavior in tactics

\section{5. 動的な行動判断モデルの構築}

$5 \cdot 1$ 学習による歩行者の判断特性の変化

前節で示した行動判断モデルは静的なモデルであり, 光の判断特性が双方の行動や環境条件に伴って変化するこ とは想定されていない .しかし，筆者らの調査 ${ }^{(11)(12)}$ の結果，駆け引き時の歩行者の行動には次の特徵が見られた . ・駆け引きは相手を発見後, 最初の 1,2 歩目のみで開始されている

・駆け引き行動の継続は優位性が改善した場合のみで, 現状維持や悪化した際には中止されている

・駆け引きが一度中止された場合に , 再度駆け引きは行われていない

静的モデルによってシミュレーションを行った場合，図 6(b) に示すように，双方の位置関係が領域 II にある限り， 駆け引き行動の開始と中止を繰り返してフラフラと迷走する不自然な挙動が起こりうる．一方，実際の歩行者の 行動には図 6(a) に示すように，駆け引きを繰り返すことなく迷走する挙動も見られない．これは，歩か淮むにつ れて交差するまでの時間的、空間的な猶予が無くなり，位置関係の優位性を逆転する可能性が低くなるため, 歩 行者が図 4(d)のように駆け引きを行わない着実な方向に判断特性を変化させていると考えることができる．

また，双方の行動から学習して判断特性を変化させることも，経験的に納得がいく. 例えば, 強引な判断特性を 持つ歩行者同士が出会った場合にも，衝突するまでイン側を取り合うことはまれで，どちらかが脱落して弱気と なる方向に判断特性を変化させ，乥の後はイン側とアウト側のコースを分け合うことが考えられる．また，相手 の性質に関し，初期の予想と実際が異なる場合も，相手の行動から弚の性質を学習し，相手の利得構造を修正す ることでスムーズなすれ違いを実現していると考えられる．

以上の仮説に従い, 従来の静的モデルに判断特性に関する学習を組み込んで, 相手の行動に対して動的に適応 するモデルへと拡張する．本論文では図 7 に示すように，次の $2 つ$ つ枠組みでモデル化を考える . 一つは, 歩行 者の相互影響に伴う戦略選択確率の変化のモデル化であり，進化ゲームによってモデルを拡張する．もう一つは， 


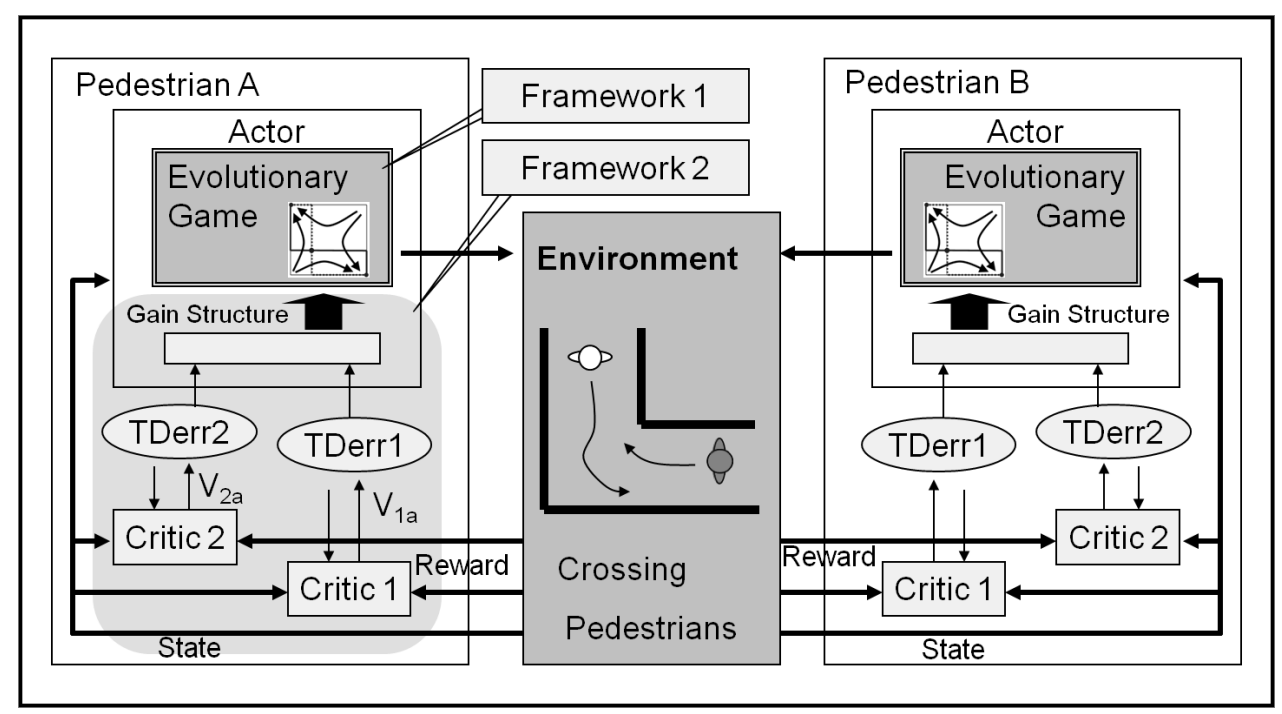

Fig. 7 Structure of learning

環境条件の変化等, すなわち, 一歩進むごとに L 字通路における自分の位置や相手との相対的な関係か変化する ことに伴う判断特性の変化のモデル化であり, 強化学習により利得構造の学習を行う . 進化ゲームは特定の利得構 造における戦略選択の変化を取り扱い, ここに強化学習で学習した利得構造を導入する。

\section{$5 \cdot 2$ 進化ゲーム理論へのモデル拡張}

相互影響による戦略選択確率の変化のモデル化については，進化ゲームの試行錯誤ダイナミクス ${ }^{(17)}$ を適用する . 試行錯誤ダイナミクスでは, 式(13)に示すロス・エレブの基本方程式により行動結果による「内心の変化」を差分 方程式で表現する「内心」は戦略選択のモチベーションにあたり，兴の変化によって戦略選択の傾向が変化する。

$$
T_{i j}(t+1)=(1-\phi) T_{i j}(t)+R_{i j}(t)
$$

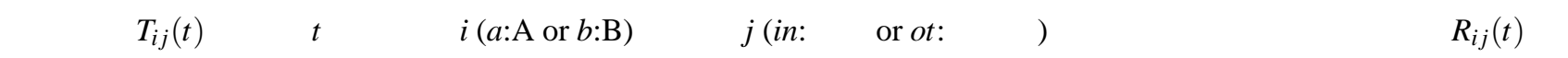
学習の強化值を, $\phi$ は忘却を示す係数を示している.このとき, 戦略の選択確率 $x_{i j}(t)$ は下式で表される.

$$
x_{i j}(t)=T_{i j}(t) / \sum_{k} T_{i k}(t)
$$

また,$x_{i j}(t)$ の時刻 $t$ から $t+1$ の間の変化量 $\Delta x_{i j}$ は下式で与えられる.

$$
\Delta x_{i j}=\left(R_{i j}(t)-x_{i j}(t) \sum_{k} R_{i k}(t)\right) / \sum_{k} T_{i k}(t+1)
$$

ここで, 強化值 $R_{i j}(t)$ に戦略選択時の利得構造を代入することで, 戦略の選択確率の変化が求まる.

表 1 をもとに戦略の選択確率, すなわちアウト側コースの選択確率 $(P a, P b)$ の変化の期待值を算出すると図 8 のようになる . 左表は, 右グラフに示す各 Area でのコースの選択確率の変化の正負を示している . 例えば,$P a$ と $P b$ が Area 1 内に位置する場合, $P a$ は小さくなる方向に変化し $P b$ は大きくなるように変化することが期待さ れる. 各 Area の境界は最適反応戦略の閾値 $(B a, B b)$ で与えられ , Area 毎の $P a, P b$ の遷移方向はグラフ中の細 矢印で示される方向となる.このような Area 毎の遷移によって，系全体として太矢印に示すような大きな遷移の 流れとなっており，最終的には左上，右下のいずれかに収束する .ここは，両歩行者がインとアウトを分け合う コースの選択確率を示しており，両者がコースを分け合って衝突を回避し，無事すれ違いを完了するように遷移し ていくことが判る .

\section{3 強化学習による利得構造の学習}

利得構造の学習には, 逐次学習を行う TD 誤差学習の一つであるアクター・クリティック法 ${ }^{(18)(19)}$ を導入する . こ の方法は脳内の学習の仕組みに近いと考えられており ${ }^{(20)}$, 本課題には最適な学習方法であると考える.ここでは, 


\begin{tabular}{|c|c|c|}
\hline \multirow{2}{*}{ Area } & \multicolumn{2}{|c|}{$\Delta x_{i j}$} \\
\cline { 2 - 3 } & $i=a, j=o t$ & $i=b, j=o t$ \\
\hline 1 & - & + \\
\hline 2 & - & - \\
\hline 3 & + & + \\
\hline 4 & + & - \\
\hline & $\downarrow$ & $\downarrow$ \\
& $\Delta \mathbf{P a}$ & $\Delta \mathbf{P b}$
\end{tabular}

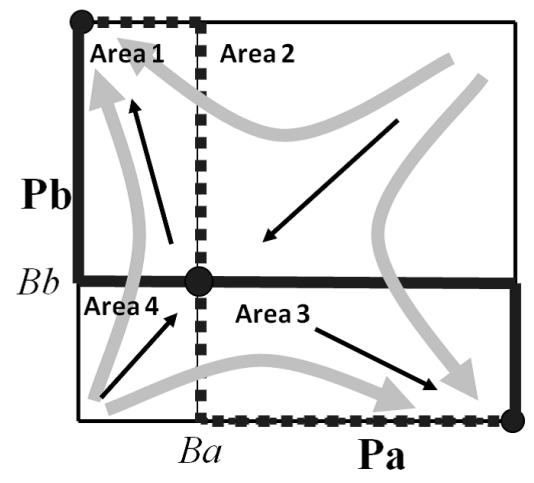

Fig. 8 Tendency of strategy choice

アクターは前節の進化ゲームモデルとなり，クリティックによって評価した結果が利得構造として引き渡される． また , 本モデルでは判断特性を表す $M_{B}$ と $W_{B}$ を学習するために 2 つクリティックを設けている . 以下に , アク ター・クリティック法による強化学習の基本式を示す.

$$
\begin{aligned}
T D_{e r r_{i j}} & =r_{t+1_{i j}}+\gamma_{i j} V_{i j}\left(S_{t+1_{i j}}\right)-V_{i j}\left(S_{t_{i j}}\right) \\
V_{i j}\left(S_{t_{i j}}\right) & =V_{i j}\left(S_{t_{i j}}\right)+\alpha_{i j}\left(T D_{e r r_{i j}}\right)
\end{aligned}
$$

式 (16) は学習の内容 $i\left(1: M_{B}\right.$ or 2: $\left.W_{B}\right)$ と歩行者 $j(a: \mathrm{A}$ or $b: \mathrm{B})$ に関する TD 誤差 $T D_{e r r_{i j}}$ の算出式で, $r_{t_{i j}}$ は時間 $t$ に おける報酬を， $V_{i j}\left(S_{t i j}\right)$ は時間 $t$ の状態 $S_{t_{i j}}$ の価値関数を， $\gamma_{i j}\left(0 \leq \gamma_{i j} \leq 1\right)$ は割引率を示す.また，式(17) は価値関 数の更新式で, $\alpha_{i j}\left(0 \leq \alpha_{i j} \leq 1\right)$ は学習率を示す.

ここで, $M_{B}$ の学習では, 状態 $S_{t_{1 j}}$ を相手のコース選択とし, 価值関数 $V_{1 j}\left(S_{t_{1 j}}\right)$ を相手のイン側選択率の期待値 $(0 \sim 1)$ とし，イン側選択率の実績との差分を報酬として与える.アクターでは実績が価值関数の值より上の場合， 相手が予想より強引であると判断して $M_{B}$ を下げる . 逆の場合は上げる方向で更新する .

$W_{B}$ の学習では, 状態 $S_{t_{2 j}}$ を優位性とし, 価値関数 $V_{2 j}\left(S_{t_{2 j}}\right)$ を駆け引き成功の可能性の増減として与える . ここ では，優位性か改善した場合に，アクターで $W_{B}$ を広げる方向となるように正の報酬を与える．逆に，維持または 悪化の場合は， $W_{B}$ を狭める方向となるように負の報酬を与える .これによって, 相手との位置関係が有利に変化 した場合に，歩行者は駆け引きによる逆転の可能性が上がると考え，より高い確率て駆け引きを行うようになる． 乥うでない場合には, 駆け引きによる逆転の可能性が下がると考えて, 駆け引きを控える樣子を再現する．

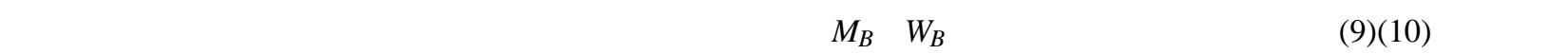
$B a, B b$ が算出され，式(11)(12) によって $K a, K b$ に変換することができる.すれ違いは $3 \sim 6$ 歩程度で完了する ため, 歩行者は数歩分しか学習できず, 必ずしも収束を目指すものではない．また，回避利得の絶対値は衝突利得 より小さいため, $K a, K b$ は $0.0 \sim 1.0$ となり，学習もこれらの值の範囲に限定される.

\section{6. シミュレーションによる有効性検証}

6.1 行動シミュレータによる検証

本論文では、判断特性の変化を考慮したモデルの挙動を, モデルを基に歩行者の歩行経路やすれ違いの樣子を 再現する行動シミュレータにより検証する．行動シミュレータとは，後述のモデルで光の行動特性が与えられる 仮想的な歩行者の挙動を計算するものであり，乥のイン側かアウト側かのコース選択の判断に提案モデルを導入 する .ここでは, 以下に示す歩行者の組合せ条件のもとですれ違いをシミュレートした .

Setting 12 人の歩行者の判断特性が異なる：「歩行者 A:強引」対「歩行者 B:弱気」

Setting 22 人の歩行者の判断特性が同じ : 「歩行者 A:強引」対「歩行者 B:強引」

行動シミュレータでは歩行者の挙動と, 帯の時の判断特性の変化について確認する.さらに, 判断特性か変化し ない静的モデルと比較することで, 提案の動的モデルの有効性を検証する． 


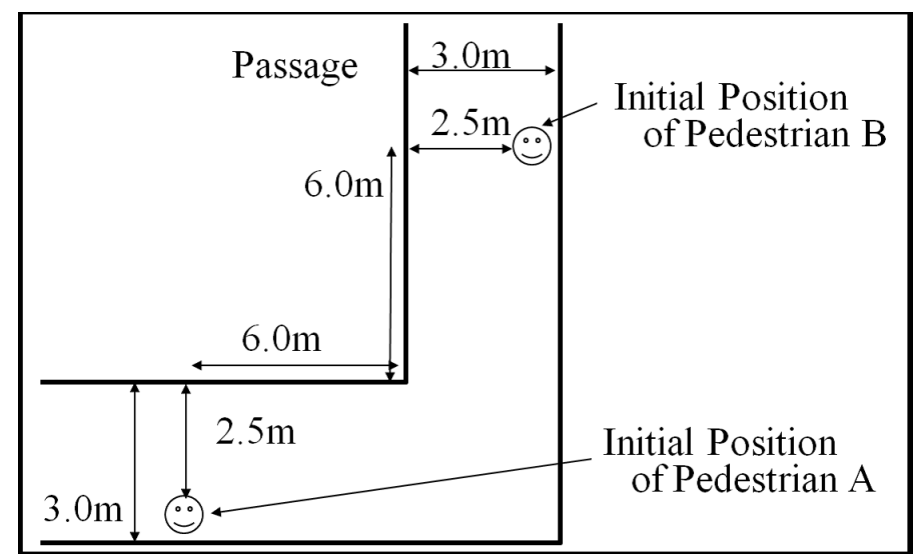

Fig. 9 Simulation setting

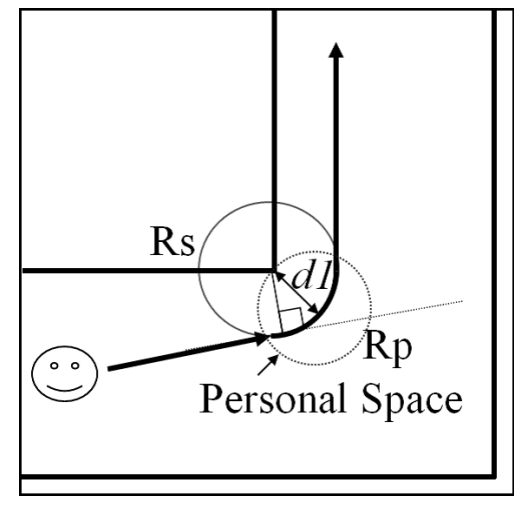

(a) Not passing

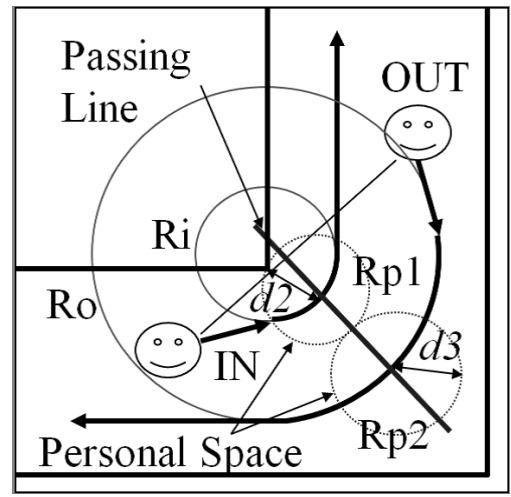

(b) Passing each other

Fig. 10 Walking path model

シミュレーションの想定環境は図 9 に示す $\mathrm{L}$ 字通路とする . 2 人の歩行者 $\mathrm{A}, \mathrm{B}$ は図中に示す初期位置より同時 にスタートする.また，歩行者の経路モデルを図 10 に示す.死角で相手が見えない領域では (a) のように , パーソ ナルスペース (Personal Space) $R p$ を考慮し，コーナー角を中心とする半径 $d 1$ の目標円 $R s$ の接線方向に進む．両 者が互いに見える領域では (b)のように，両者の交差予測位置 (Passing Line) を中心線に持ち，コーナー内壁に接 する半径 $d 2$ のイン側のパーソナルスペース $R p 1$ と,$R p 1$ に接するアウト側のパーソナルスペース $R p 2$ を考慮し た経路を歩行者は歩くものとする . イン側を通る歩行者は, コーナー角を中心として $R p 1$ の中心までを半径とす る目標円 $R i$ の接線方向に進む . アウト側を通る歩行者は, コーナー角を中心として $R p 2$ の中心までを半径とする 目標円 $R o$ の接線方向に進む. 乥して, 歩行者は一定の歩幅 $S f$ を一定の時間間隔 $T s$ で踏み出す 2 足歩行モデル ${ }^{(13)}$ に基づいて歩行を行う. 判断に必要となる歩行者 $\mathrm{A}$ の歩行者 B に対する位置関係の優位性 $p$ は, 3.1 節で説明 を行った式 (1) によって算出され，0 值を中立として值が小さいほど歩行者 A が有利となる -4 ～整数值で与 えられる．アウト側コースの選択確率 $P a(p)$ の進化ゲームによる学習前の初期值は, $p=-4.5$ の時に $0, p=4.5$ で 1 となるように, $p$ に対して均等に值を割りつける . また, 強化学習の状態 $S_{t_{1 j}}$ を相手のコース選択 (イン側 or アウト側 $)$ とし, 状態 $S_{t_{2 j}}$ を優位性 $p\left(-4 \sim 4\right.$ の整数值) として与えるものとする. 光して, 価值関数 $V_{1 j}\left(S_{t_{1 j}}\right)$, $V_{2 j}\left(S_{t_{2 j}}\right)$ は，すれ違いの開始時点で初期值にリセットするものとする . シミュレーションで用いた主要なパラメー タを表 2 に示す .ここで, 学習のパラメータは, 実際の調査結果のデータから, 想定される利得構造の变化が発 生するパラメータ領域を算出し、シミュレーションを使った試行において意図しない挙動が発生しないように絞 り込むことで, 值の決定を行っている． 
Table 2 Parameters for simulation

\begin{tabular}{|c|c|c|c|c|c|c|}
\hline \multicolumn{7}{|c|}{ Pedestrian Parameter } \\
\hline \multicolumn{2}{|c|}{ Stride of Walking: $S f$} & \multicolumn{2}{|l|}{$0.50 \mathrm{~m}$} & \multicolumn{2}{|c|}{ Personal Space: $d 1$} & $1.20 \mathrm{~m}$ \\
\hline \multicolumn{2}{|c|}{ Step Interval : Ts } & $0.60 \mathrm{~m}$ & \multicolumn{3}{|c|}{ Personal Space: $d 2$} & $0.50 \mathrm{~m}$ \\
\hline \multicolumn{2}{|c|}{ Standard Distance: $L s$} & $4.00 \mathrm{~m}$ & \multicolumn{3}{|c|}{ Personal Space: $d 3$} & $0.80 \mathrm{~m}$ \\
\hline \multicolumn{7}{|c|}{ Pedestrians' Gain } \\
\hline \multirow{2}{*}{$\begin{array}{l}\text { Pedestrian A } \\
\text { (Setting 1) }\end{array}$} & \multicolumn{2}{|c|}{ Collision Gain: $\mathrm{Ca}$} & 0.173 & \multicolumn{2}{|c|}{ Avoidance Gain: Aa } & 0.157 \\
\hline & \multicolumn{2}{|c|}{ Collision Gain: $C b$} & 0.173 & \multicolumn{2}{|c|}{ Avoidance Gain: $A b$} & 0.042 \\
\hline \multirow{2}{*}{$\begin{array}{l}\text { Pedestrian B } \\
\text { (Setting 1) }\end{array}$} & \multicolumn{2}{|c|}{ Collision Gain: $C b$} & 0.173 & \multicolumn{2}{|c|}{ Avoidance Gain: $A b$} & 0.042 \\
\hline & \multicolumn{2}{|c|}{ Collision Gain: $\mathrm{Ca}$} & 0.173 & \multicolumn{2}{|c|}{ Avoidance Gain: $A a$} & 0.157 \\
\hline \multirow{2}{*}{$\begin{array}{l}\text { Pedestrian A } \\
\text { (Setting 2) }\end{array}$} & \multicolumn{2}{|c|}{ Collision Gain: $\mathrm{Ca}$} & 0.173 & \multicolumn{2}{|c|}{ Avoidance Gain: $A a$} & 0.157 \\
\hline & \multicolumn{2}{|c|}{ Collision Gain: $C b$} & 0.173 & \multicolumn{2}{|c|}{ Avoidance Gain: $A b$} & 0.042 \\
\hline \multirow{2}{*}{$\begin{array}{l}\text { Pedestrian B } \\
\text { (Setting 2) }\end{array}$} & \multicolumn{2}{|c|}{ Collision Gain: $\mathrm{Cb}$} & 0.173 & \multicolumn{2}{|c|}{ Avoidance Gain: $A b$} & 0.157 \\
\hline & \multicolumn{2}{|c|}{ Collision Gain: $\mathrm{Ca}$} & 0.173 & \multicolumn{2}{|c|}{ Avoidance Gain: Aa } & 0.042 \\
\hline \multicolumn{7}{|c|}{ Learning Parameter $\quad *(j=a, b)$} \\
\hline \multicolumn{2}{|c|}{ Discount Rate(Critic1): $\gamma_{1 j}$} & 1.00 & \multicolumn{3}{|c|}{ Learning Rate(Critic1): $\alpha_{1 j}$} & 0.20 \\
\hline \multicolumn{2}{|c|}{ Discount Rate(Critic2): $\gamma_{2 j}$} & 1.00 & Learnir & Rate(Critic & & 1.00 \\
\hline Forgetting Fac & $r: \varphi$ & 0.00 & Rewarc & $f V_{2 j}: r_{t 2 j}$ & 0.50 & or -1.00 \\
\hline Initial Value: & $\left(\mathrm{St}_{1 j}\right)$ & 0.50 & Initial & ue: $V_{2 j}\left(\mathrm{St}_{2 j}\right)$ & & 0.00 \\
\hline
\end{tabular}

Table 3 Ratio of course selection

\begin{tabular}{|c|c|c|c|c|c|c|c|c|c|c|c|c|}
\hline \multicolumn{9}{|c|}{ Patterns of Course Selection (A : B) } & \multicolumn{2}{|c|}{ Setting 1} & \multicolumn{2}{|c|}{ Setting 2} \\
\hline \multicolumn{3}{|c|}{ 1st Step } & \multicolumn{3}{|c|}{ 2nd Step } & \multicolumn{3}{|c|}{ 3rd Step \& later } & \multirow{2}{*}{$\begin{array}{l}\text { Static } \\
0.24 \%\end{array}$} & \multirow{2}{*}{$\begin{array}{r}\text { Dynamic } \\
0.00 \%\end{array}$} & \multirow{2}{*}{$\begin{array}{r}\text { Static } \\
5.48 \%\end{array}$} & \multirow{2}{*}{$\begin{array}{r}\text { Dynamic } \\
8.55 \% \\
\end{array}$} \\
\hline IN & : & IN & IN & : & IN & OUT & : & IN & & & & \\
\hline IN & : & IN & OUT & : & IN & OUT & : & IN & $1.29 \%$ & $3.66 \%$ & $13.28 \%$ & $41.22 \%$ \\
\hline OUT & : & IN & IN & : & IN & OUT & : & IN & $3.49 \%$ & $4.96 \%$ & $15.09 \%$ & $15.68 \%$ \\
\hline OUT & : & IN & OUT & : & IN & OUT & : & IN & $5.16 \%$ & $7.56 \%$ & $22.28 \%$ & $23.92 \%$ \\
\hline OUT & : & OUT & OUT & : & OUT & OUT & : & IN & $1.18 \%$ & $0.00 \%$ & $0.00 \%$ & $0.00 \%$ \\
\hline OUT & : & OUT & OUT & : & IN & OUT & : & IN & $0.80 \%$ & $0.00 \%$ & $0.14 \%$ & $0.00 \%$ \\
\hline OUT & : & OUT & IN & : & IN & OUT & : & IN & $1.18 \%$ & $5.20 \%$ & $0.21 \%$ & $0.17 \%$ \\
\hline OUT & : & OUT & IN & : & OUT & OUT & : & IN & $1.75 \%$ & $0.00 \%$ & $0.00 \%$ & $0.00 \%$ \\
\hline IN & : & OUT & OUT & : & OUT & OUT & : & IN & $0.00 \%$ & $0.00 \%$ & $0.00 \%$ & $0.00 \%$ \\
\hline IN & : & OUT & OUT & : & IN & OUT & : & IN & $0.01 \%$ & $0.00 \%$ & $0.00 \%$ & $0.00 \%$ \\
\hline IN & : & OUT & IN & : & IN & OUT & : & IN & $0.00 \%$ & $0.00 \%$ & $0.00 \%$ & $0.00 \%$ \\
\hline IN & : & OUT & IN & : & OUT & OUT & : & IN & $0.00 \%$ & $0.00 \%$ & $0.00 \%$ & $0.00 \%$ \\
\hline IN & : & IN & IN & : & IN & IN & : & OUT & $3.60 \%$ & $0.44 \%$ & $3.33 \%$ & $1.12 \%$ \\
\hline IN & : & IN & IN & : & OUT & IN & : & OUT & $8.56 \%$ & $4.73 \%$ & $0.31 \%$ & $0.00 \%$ \\
\hline IN & : & OUT & IN & : & IN & IN & : & OUT & $0.64 \%$ & $6.59 \%$ & $0.21 \%$ & $0.44 \%$ \\
\hline IN & : & OUT & IN & : & OUT & IN & : & OUT & $34.19 \%$ & $28.95 \%$ & $0.21 \%$ & $0.17 \%$ \\
\hline OUT & : & OUT & OUT & : & OUT & IN & : & OUT & $2.35 \%$ & $0.00 \%$ & $0.00 \%$ & $0.00 \%$ \\
\hline OUT & : & OUT & IN & : & OUT & IN & : & OUT & $5.12 \%$ & $16.79 \%$ & $0.00 \%$ & $0.00 \%$ \\
\hline OUT & : & OUT & IN & : & IN & IN & : & OUT & $3.47 \%$ & $2.04 \%$ & $0.01 \%$ & $0.00 \%$ \\
\hline OUT & : & OUT & OUT & : & IN & IN & : & OUT & $3.47 \%$ & $0.00 \%$ & $0.01 \%$ & $0.00 \%$ \\
\hline OUT & : & IN & OUT & : & OUT & IN & . & OUT & $1.34 \%$ & $0.00 \%$ & $0.00 \%$ & $0.00 \%$ \\
\hline OUT & : & IN & IN & : & OUT & IN & ( & OUT & $0.91 \%$ & $0.19 \%$ & $0.00 \%$ & $0.00 \%$ \\
\hline OUT & : & IN & IN & : & IN & IN & : & OUT & $0.00 \%$ & $0.00 \%$ & $0.00 \%$ & $0.00 \%$ \\
\hline OUT & : & IN & OUT & : & IN & IN & : & OUT & $0.00 \%$ & $0.00 \%$ & $0.00 \%$ & $0.00 \%$ \\
\hline & & & & & & & & 合計 & $78.76 \%$ & $81.11 \%$ & $60.57 \%$ & $91.28 \%$ \\
\hline
\end{tabular}

\section{$6 \cdot 2$ 行動シミュレータの結果}

行動シミュレータによって, 歩行者の各判断時のコース選択の確率を算出することが可能となる. 光の選択確 率をすれ違い完了まで順に算出して掛け合わせていくと，あるコースの選択パターン (例えば、イン $\Rightarrow$ あ $\Rightarrow イ$ ン のようなコース選択) がどのくらいの確率で選ばれるのかを算出することができる．このように，実際の現 場調査で見られた下記の特徵を満たすコース選択が, どの程度の確率で生じるかを静的なモデルと動的なモデル 
によって比較を行った．

・駆け引きは相手を発見後, 最初の 1,2 歩目のみで開始されている

・駆け引き行動の継続は優位性が改善した場合のみで, 現状維持や悪化した際には中止されている

・駆け引きが一度中止された場合に , 再度駆け引きは行われていない

表 3 に谷の結果を示す.表は，上記の条件を満たすコース選択のパターンと，設定条件 1 (Setting 1) と設定条件 2 (Setting 2) における静的モデル (Static) と動的モデル (Dynamic) での关のパターンの発生確率を示している . また 表中の灰色のマスは，この設定条件では発生しないパターンを示している.表より，どちらの設定条件において も上記条件を満たすパターンの発生確率の合計は，動的モデルの方が高くなっていることが判る. 設定条件 1 は 「強引」と「弱気」の組合せで, 比較的両者のコース取りがはっきりしやすいため, 静的モデルも高い確率で上記 条件を満たし，大きな差は見られなかった．しかし，この場合でも動的モデルの方が高い確率で条件を満たして おり，コース選択のパターンも静的モデルより少なく，確率的に樣々なコースを取るのではなく，ある程度絞りこ まれたコース取りを高い確率で選択していることが判る.設定条件 2では「強引」同士の組合せのため，動的モ デルの効果か顕著に表れている . 静的モデルでは両者が張り合って, 確率的なコース選択が多くなるため, 上記 の条件を満たす確率が約 $60 \%$ と低くなっている.一方, 動的モデルでは判断特性の変化により，どちらかがイン 側に向うのを諦めるとコース選択がはっきり分かれる樣子を再現しており，上記の条件を $90 \%$ を超える高い確率 で満たしている．また，設定条件 1 の場合と同樣に，取り得るコース選択のパターンも静的モデルよりも絞り込 まれていることが判る . 以上のように, より実際の歩行者のコース選択のパターンに近いコース取りを再現して いることが判る．

また , シミュレータによるコース選択と歩行者の歩行経路の例として , 設定条件 1 (Setting 1) での結果を図 11

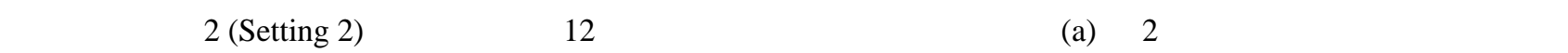
しており，特に死角を外れて互いに相手が見える状態 (Finding) から交差する直前まで (以下，「すれ違い中」と言 う）の，一歩毎の歩行者の位置を示している.ここで, すれ違い中に要した歩数は光れ光れ 6 歩と 5 歩であり，こ れが以降 (b)〜 (d) のグラフの横軸に反映している. (b) はすれ違い中の歩行者 A の優位性 (Superiority) と, 乥れ光

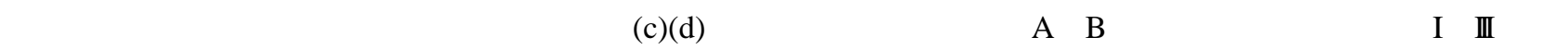
合と $M_{B}$ の值, さらにアウト側コースの選択確率 $(P a, P b)$ の変化を示している.上記の判断特性の変化を考慮し た動的モデルの場合の值に加えて, 判断特性が変化しない静的モデルの場合での值も示している. 静的モデルの 場合の判断特性を示す領域は, Fixed Area で示される点線で与えられ, コースの選択確率の遷移は $P a$ fix と $P b$ fix で示される。

設定条件 1 では，以下の歩行者の挙動が見られた . 図 11(a)(b) より，すれ違い中は歩行者 B が位置的な優位性 を保ち続け，歩行者 A がアウト側、歩行者 B がイン側のコースを選択し続けている . 弚の結果 , 歩を進めるごと に歩行者 B の優位性が増し, 当初は弱気な判断特性であった歩行者 B がコーナーのイン側を勝ち取り，強引な判 断特性を持っていた歩行者 A がアウト側で交差している.

この時の判断および判断特性の遷移は, 図 11(c)(d)より以下のようになっている.最初の 1 歩目は両者とも駆け 引きの領域 II にあが , この試行では優位性通りに歩行者 A がアウト側 , 歩行者 B がイン側のコースを選択して いる. 炎の 1 歩目のコース選択の結果によって, 歩行者 B は「弱気」から「強引」の方向に判断特性を变化させ ている．一方，歩行者 A は「強引」な傾向は維持するが，弚の強引さの度合いは下げている．また，歩を増すご とに両者の「戦略」的な傾向が弱まり「着実」な特性に変化している.このような判断特性の変化によって, 3 歩 目には歩行者 A がアウト側 , 歩行者 B がイン側を選択する領域 III となり，以降すれ違いが完了するまでイン側と アウト側の選択が明確に分かれる樣子が見られる.これに対して, 判断特性が変化しない場合は判断の閾値が固 定され (Fixed Area)，図に見られるように，両歩行者のコース選択確率 ( $P a$ fix , $P b$ fix) は常に駆け引きの領域と なるため，コース選択か確率的となって迷走する可能性があることが判る．

設定条件 2 のシミュレーションでは，以下のような歩行者の挙動が見られた . 図 12(a)(b)より，すれ違い中は 歩行者 B が位置的な優位性を保ち続け，優位性にしたがって常にイン側のコース選択をしている．他方，歩行者 $\mathrm{A}$ は最初の 1 歩目だけイン側を選択したのち、2 歩目以降はアウト側のコースを選択している . これは , 歩行者 $\mathrm{A}$ が 1 歩目に駆け引きに出てイン側のコース選択を行ったが , 優位性が改善しなかったためイン側を止めて , 以降 アウト側を選択したことを再現している．3 歩目以降は優位性の差が明らかになり，歩行者 A がアウト側 , 歩行 


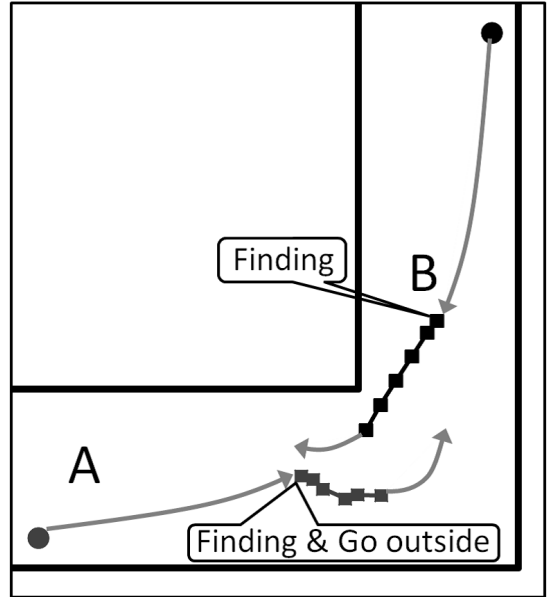

(a) Path of pedestrians

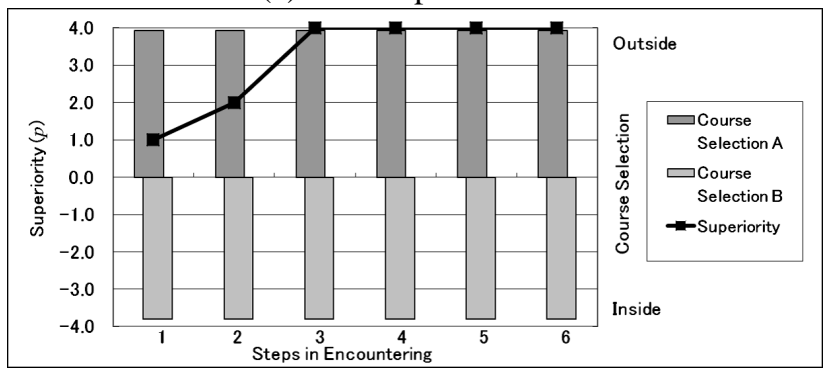

(b) Superiority and course selection

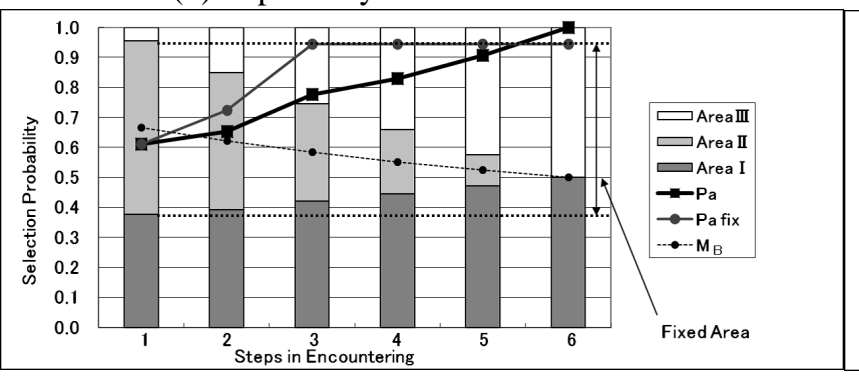

(c) Judgments and selection probability (pedestrian A)

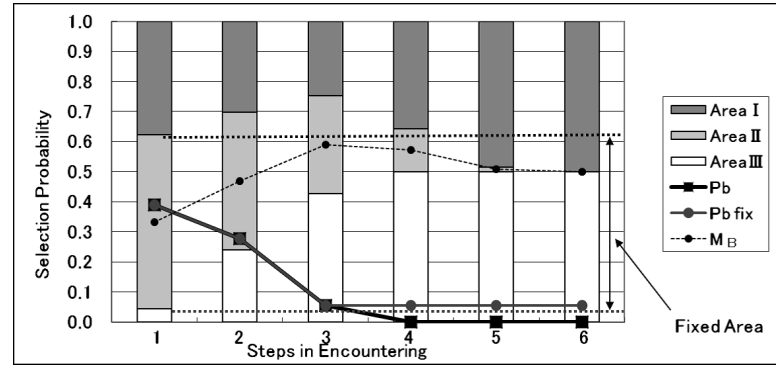

(d) Judgments and selection probability (pedestrian B)

Fig. 11 Results of simulation (setting 1)

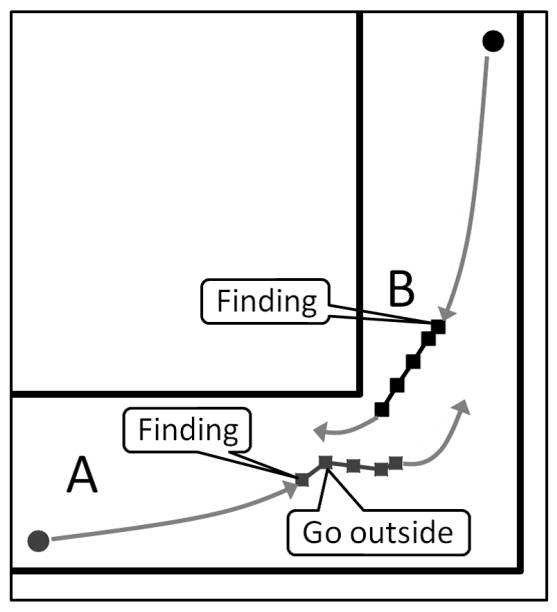

(a) Path of pedestrians

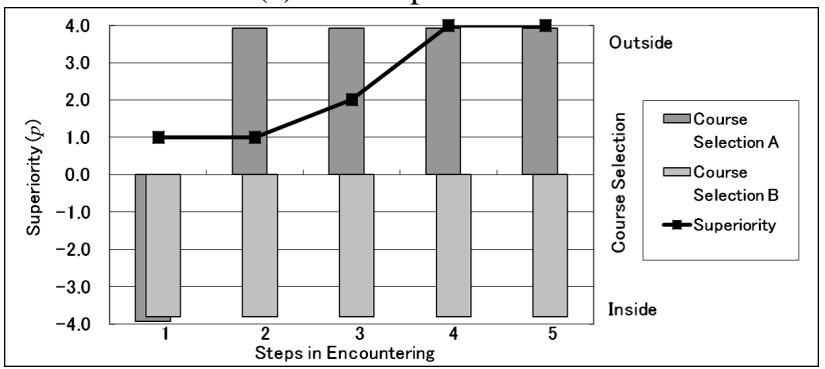

(b) Superiority and course selection

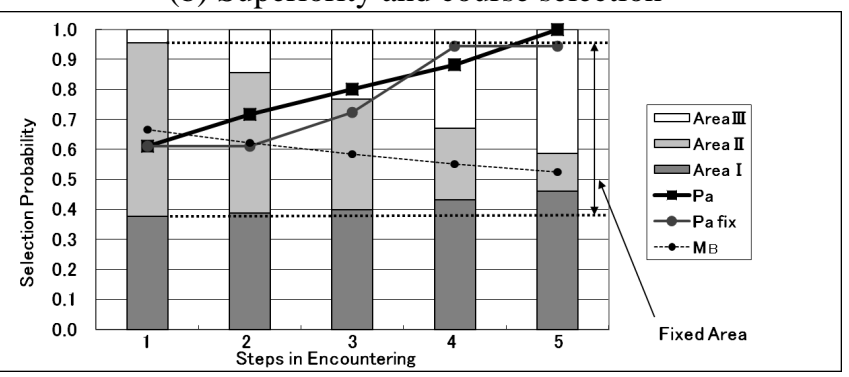

(c) Judgments and selection probability (pedestrian A)

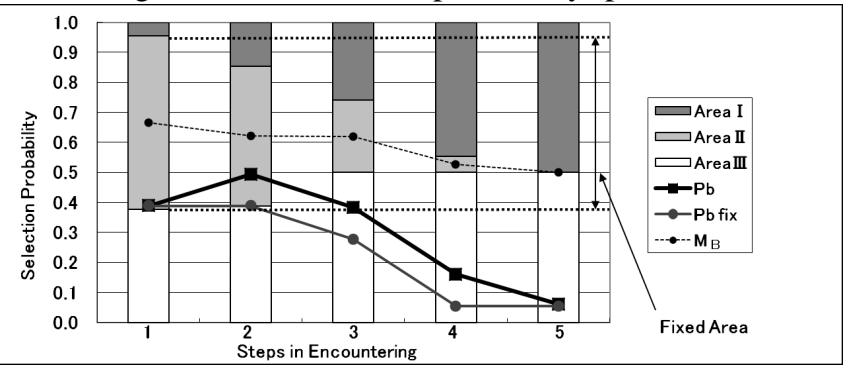

(d) Judgments and selection probability (pedestrian B)

Fig. 12 Results of simulation (setting 2)

者 B がイン側のコース選択を継続して，すれ違いを完了している．

この時の判断および判断特性の遷移は, 図 $12(\mathrm{c})(\mathrm{d})$ より以下のようになっている.最初の 1 歩目は両者とも駆け 引きの領域 II にあり，歩行者 A か駆け引きの行動に出たため，両歩行者ともイン側のコースを選択している . 光 の後 , 歩行者 A の駆け引きは失敗に終わり，以降の判断特性では徐々に「強引」さの度合いを低くし，「着実」な 方向に変化させている.一方, 位置的に優位な歩行者 B は「強引」さを維持した後に，急激に「着実」な方向に判 断特性を変化させている. 兴の結果，3 歩目以降は歩行者 A がアウト側, 歩行者 B がイン側を選択する領域 III に コースの選択確率が遷移し, 以降すれ違いが完了するまでイン側とアウト側の選択が明確に分かれていく樣子が 
Table 4 Pedestrians' gain (case 1 \& case 2)

\begin{tabular}{|l|c|l|l|}
\hline \multicolumn{2}{|c|}{ Pedestrian A } & \multicolumn{2}{c|}{ Pedestrian B } \\
\hline Collision Gain: Ca & 0.173 & Collision Gain: Cb & 0.173 \\
\hline Avoidance Gain: Aa & 0.081 & Avoidance Gain: Ab & 0.081 \\
\hline Collision Gain: Cb & 0.173 & Collision Gain: Ca & 0.173 \\
\hline Avoidance Gain: Ab & 0.081 & Avoidance Gain: Aa & 0.081 \\
\hline
\end{tabular}

見られる.これに対して, 判断特性が変化しない場合は固定された判断の閾値 (Fixed Area) に対し , 歩行者 A の コースの選択確率 ( P $a$ fix ) が常に駆け引きの領域にあり，コース選択が確率的となり迷走する可能性があること が判る。

設定条件 1 では，位置関係にしたがって両歩行者の判断特性の「強引」「弱気」の関係が逆になる樣子が見られ た .さらに, 歩が進むにつれて優位性が逆転する可能性が無くなるため「着実」な方向に判断特性を変化させてい く樣子も見られた．また，設定条件 2 では，最初に両歩行者が「強引」な判断特性によってイン側のコースを取 り合っていたが 2 歩目に歩行者 A がアウト側に避けると，以降の両者の判断特性に差がつく樣子が見られた . ど ちらの設定条件も，最初の 2 歩目までは両者のコースの選択確率か駆け引きの領域にあったが， 3 歩目以降は駆け 引きの領域から外れ，イン側とアウト側に分かれて遷移している樣子が見られる. 以上のように , コース選択と 歩行者の経路の例からも，現場調査で見られたコース選択の特徵に一致する挙動が確認できており，また，判断 特性の変化を考慮しない場合に見られる不自然な迷走の発生の可能性も少なく, より実際に近い歩行者の挙動を 再現できていると考えられる .

$6 \cdot 3$ 判断シミュレータによる検証

以下では, 実際の歩行者のすれ違いの挙動に対して, 提案モデルを用いて歩行者の判断をシミュレートするこ とでモデルの妥当性の検証を行う . シミュレーションを行うモデルケースとして , 現場調査 ${ }^{(11)}$ の結果から以下の 2つのケースを設定した .

Case 1 駆け引きを行ったが優位性を逆転できずアウト側に戻った

一方の歩行者が 2 歩目に駆け引きでイン側のコース選択を行ったが成功せず，アウト側に戻った . 結果とし て最初の優位性通りのコースによってすれ違いを行った .

Case 2 駆け引きを行うことで優位性が逆転した

一方の歩行者が 1 歩目に駆け引きによってイン側のコースを選択した結果 , 優位性が逆転した . 光の結果 , 相

手がアウト側にコースを変更し, 最初の優位性とは逆のコースによってすれ違いを行った .

以上のケースでの実際の歩行者の経路と光の時のコース選択の結果を基に，提案モデルにしたがって判断特性と コースの選択確率の遷移をシミュレートする .ここでは, シミュレートされた判断と実際の判断（選択されたコー ス) を比較することで提案モデルの妥当性を検証する . また, 併せて判断特性か変化しない静的モデルとの比較も 行う.ここで, シミュレートする歩行者の初期の判断特性として, 表 4 の利得を設定した . これらの利得は, 現 場調査から得られた結果 ${ }^{(12)}$ から算出したものである .

\section{$6 \cdot 4$ 実際の調査結果と判断シミュレータの結果の照合}

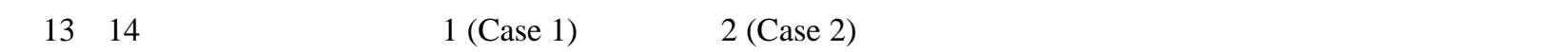
結果を示している. 产れ光れの図において，(a) は2 人の歩行者が実際に歩いた経路を示しており，すれ違い中は 一歩毎の歩行者の位置を示している .ここで, すれ違い中に要した歩数はどちらのケースも 4 歩であり，以降 (b) 〜(d) のグラフの横軸に反映している . (b) はすれ違い中に歩行者が実際に選択したコースと歩行者 A の優位性を 示している. (c)(d) は, 弚れ光れすれ違い中の歩行者 $\mathrm{A}, \mathrm{B}$ の判断特性を示す領域 I〜III の割合と $M_{B}$ の値，さらに アウト側コースの選択確率 $(P a, P b)$ の変化を示している.ここでは, 上記の判断特性の変化を考慮した動的モデ ルの場合の值に加えて, 判断特性か湾化しない静的モデルの場合での値も示している. 静的モデルの場合の判断特 性を示す領域は Fixed Area で示される点線で与えられ, コースの選択確率の遷移は $P a$ fix と $P b$ fix で示される. 


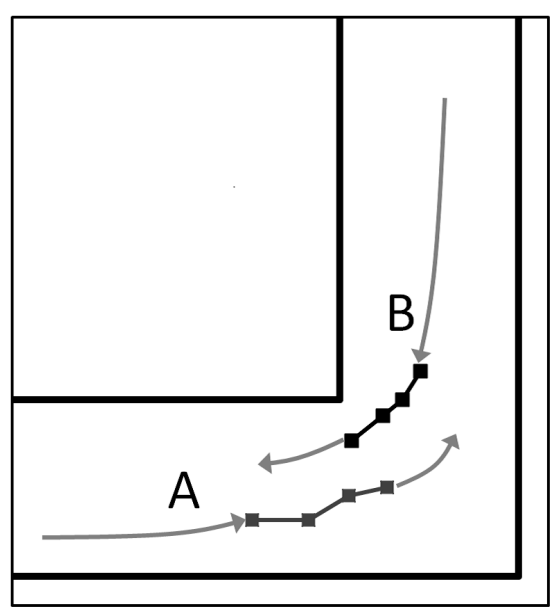

(a) Path of pedestrians

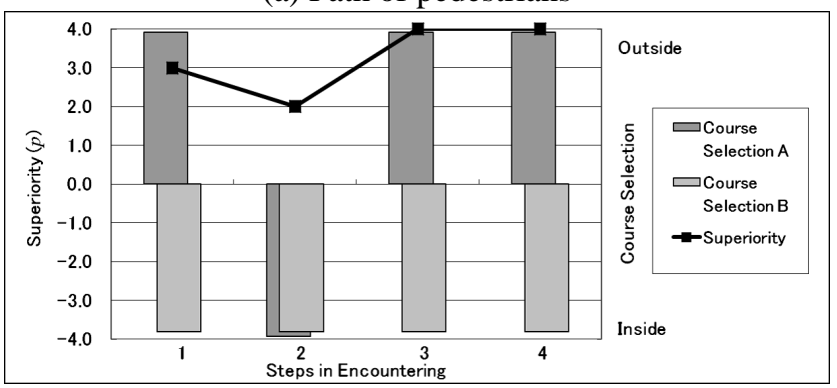

(b) Superiority and course selection

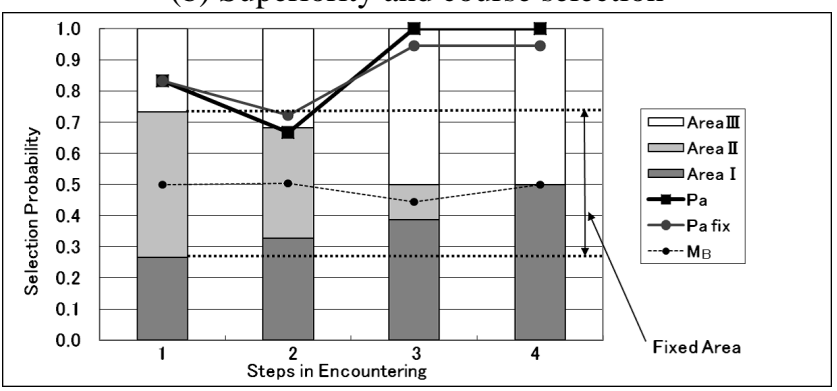

(c) Judgments and selection probability (pedestrian A)

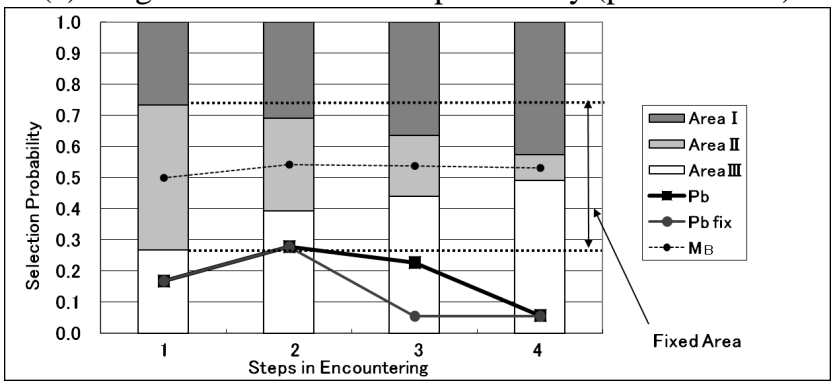

(d) Judgments and selection probability (pedestrian B)

Fig. 13 Simulation of judging (case 1)

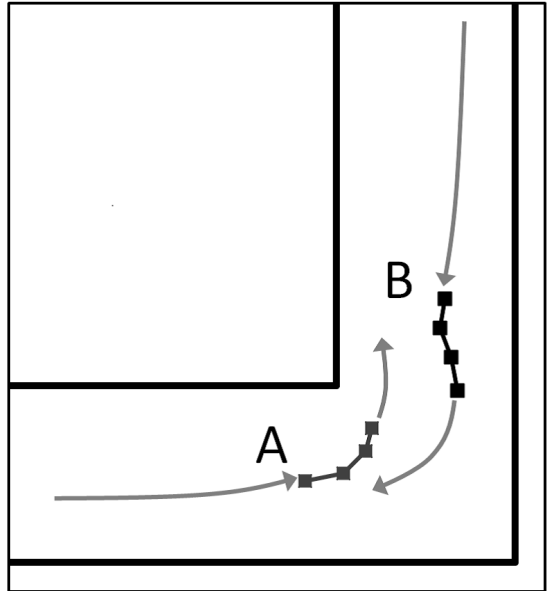

(a) Path of pedestrians

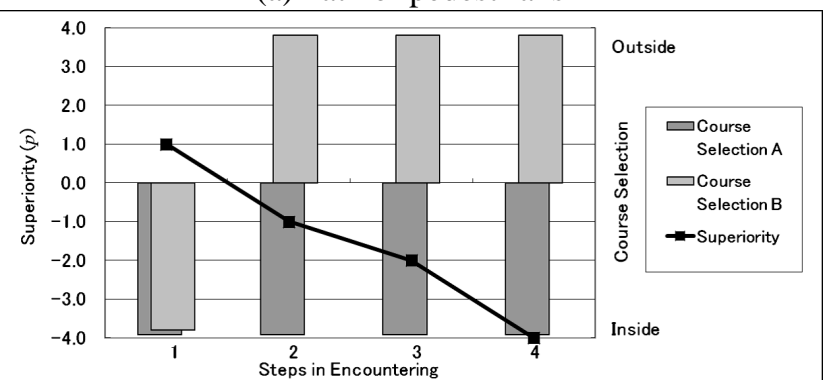

(b) Superiority and course selection

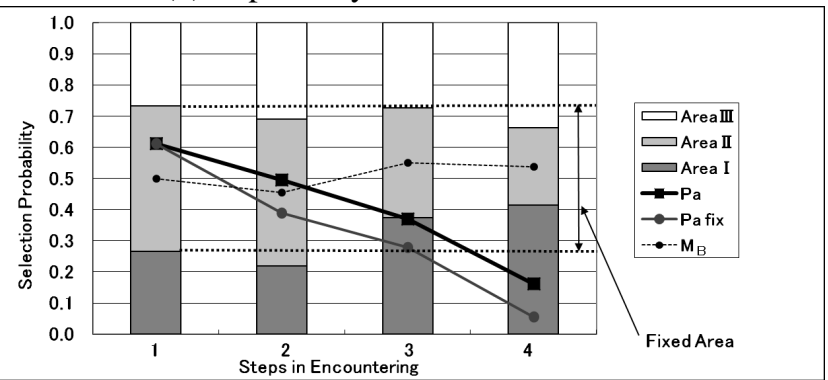

(c) Judgments and selection probability (pedestrian A)

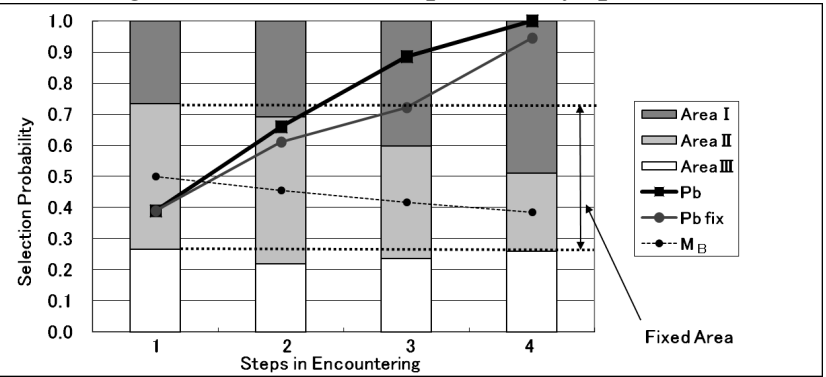

(d) Judgments and selection probability (pedestrian B)

Fig. 14 Simulation of judging (case 2)

図 13(a)(b)より，ケース 1 では歩行者は以下に記す行動とコース選択を行っている . 歩行者 A は 1 歩目から位 置的に不利な状況にあったが， 2 歩目で優位性が改善したため駆け引きの行動に出てイン側のコースを選択した . しかし , 3 歩目で再び優位性が悪化したため, 駆け引きをやめてアウト側のコースを選択している . 一方 , 歩行者 B は位置的な優位性にしたがってイン側のコースを選択し続けた .

このケースでの判断をシミュレートした結果を図 13(c)(d) に示す. 判断特性は歩行者 A ，B ともに「戦略」的な 傾向か弱まり，「着実」な判断特性に変化させている.特に，歩行者 A は「弱気」な傾向を示しつつ，他方で歩行 
者 B は「強引」な傾向を示しつつ判断特性を変化させている.コースの選択確率は, 歩行者 $\mathrm{A}$ がイン側を選択し た 2 歩目だけ駆け引きの領域 II となり，弚れ以外は両者とも領域 III にあって歩行者 $\mathrm{A}$ がアウト側、歩行者 $\mathrm{B}$ がイ ン側のコース選択を行っている．すなわち，歩行者 $\mathrm{A}$ の 2 歩目のみ駆け引きを行う機会があり，歩行者 $\mathrm{A}$ は駆け 引きの行動に出たが, 光れ以外は両歩行者とも優位性に従ってコースが確定されていたことが判る.この結果は 実際の歩行者の行動に一致し、駆け引きの判断の必要性も合理的に説明できるものとなっている．

一方, 判断特性が変化しない静的モデルの場合, 歩行者 B のコースの選択確率も 2 歩目か溤呵引きの領域 (Fixed Area の内側) となっている. 光の歩行者 B の 2 歩目において優位性に従ったイン側が選択されれば，実際の判断 結果と一致する結果が得られるが，不自然な行動となるアウト側の選択も許容するものであり，乥こで駆け引き の判断が必要である理由は合理的に説明できない .

図 14(a)(b)より，ケース 2 では歩行者は以下に記す行動とコース選択を行っている．1 歩目は歩行者 B が優位で あったが, 歩行者 A か駆け引きの行動に出て , 両者ともイン側のコースを選択している .この時の歩行者 A の駆 け引きは成功し，2 歩目に優位性が逆転している.以降は両者とも優位性に従ってコース選択を行い, 歩を進める ごとに位置的な優位性の差が大きくなっている．

このケースでの判断をシミュレートした結果を図 14(c)(d) に示す. 判断特性はコース選択が分かれた 2 歩目以降 で, 歩行者 $\mathrm{A}$ は徐々に「強引」な判断特性に変化し, 歩行者 $\mathrm{B}$ は徐々に「弱気」な判断特性に变化している.ま た、両者の判断特性は徐々に「着実」な方向へ変化している. 帯の結果，コースの選択確率は歩行者 $\mathrm{A}, \mathrm{B}$ とも 2 歩目までは駆け引きの領域 II にあったが，光れ以降は，両者とも歩行者 A がイン側 , 歩行者 B はアウト側のコー ス選択を行う領域 I となっている．すなわち，一歩目に歩行者 A は駆け引きに出て優位性の逆転を引き起こした が, 歩行者 B は 2 歩目に駆け引きを行わなかったため, 以降の両者のコースは優位性に従って確定されていたこ とが判る.この結果は実際の歩行者の判断結果に一致し、駆け引きの判断の必要性も合理的に説明できる.

一方, 判断特性が変化しない静的モデルの場合, 歩行者 A， B のコースの選択確率がどちらも 3 歩目まて駆け 引きの領域となっている. 3 歩目に両者とも優位性に従うコース選択をした場合には, 実際の判断結果と一致する

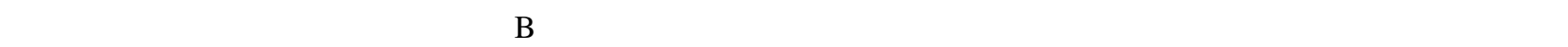
となり，これを許容する駆け引きの判断の必要性は合理的に説明できない .

以上の結果 , ケース 1, ケース 2 のいずれの場合も，提案の動的モデルを用いて算出された判断結果が実際の行 動判断の結果に一致し，駆け引きの判断の必要性も合理的に説明できるものとなっている . 従来の静的モデルの 場合も実際の結果に一致する判断結果が得られるが,「どちらの歩行者がイン側を取るか」の大勢が決まる 2〜 3 歩目以降での駆け引きの領域への遷移によって，不自然な行動を許容する駆け引きの判断を行うことになり，提案 の動的モデルがより実際に近い判断を再現していることが判る．また，ここで紹介した 2 ケース以外にも現場調 査のすれ違いの結果 13 例に対して , 判断のシミュレーションを行ったが同樣の結果が得られている.

\section{5 シミュレーションによる検証のまとめ}

上記の検証の結果，提案のモデルを用いた歩行者の行動シミュレータによって，現場調査で得られた歩行者の 特徵的なコース取りを高い確率で実現し，より自然で人の行動に近い歩行者の判断特性および行動が再現できる ことを確認できた . また，実際の行動結果をもとに判断シミュレータで算出された判断が，実際の判断結果に一 致し, 駆け引きの判断の必要性も合理的に説明できるものであることが確認できた . 以上より, 判断特性の動的 な変化を考慮した提案のモデルの有効性を確認することができた .

\section{7. 結 言}

本論文では，L字通路での歩行者のすれ違い時における行動判断モデルに関して，すれ違いを行う間に状況に 併せて判断特性か変化するダイナミクスを再現するモデルの提案を行った .すなわち , まずゲーム理論の最適反 応戦略に対応して，すれ違いに向かう歩行者のコース取りの選択確率が優位性に従う領域と従わない駆け引きの 領域の大きさに着目した . 光して，これらを特徵的に定量化する指標の導入を行い，歩行者の性質および判断特 性と関連付けられる考察を行い，これをモデル化する提案を行った . 提案モデルでは，従来の静的モデルで用い たゲーム理論を進化ゲームに拡張することにより, 特定の利得構造のもとでの相互影響による特性变化の樣子を 
再現した .さらに, 逐次学習のアクター・クリティック法を用いることで, 環境条件等の変化によって利得構造を 学習し, 環境変化に伴う判断特性の変化を再現するモデル化を行った . また, 本モデルを導入したシミュレーショ ンによりモデルの有効性を検証した . 光の結果と，歩行者のタイプによる判断特性の違いを示すことができ，従 来のモデルに較べてより自然でスムーズなすれ違いを実現することができた .

\section{文献}

(1)“学校施設における事故防止の留意点について (第 1 次報告) ”, 文部科学省大臣官房文教施設企画部, (2008).

（2）“施設整備マニュアル（移動に関する事項 2 ）”，だれもが住みたくなる福祉滋賀のまちづくり条例 (2004).

(3) 岡崎 甚幸,“建築空間における歩行のためのシミュレーションモデルの研究: 兴の 1. 磁気モデルの応用による歩行モデ ル”,日本建築学会 論文報告集, No.283 (1979), pp. 111-119.

(4) Sommer, R., Personal Space: The Behavior Basis of Design (1969), Englewood Cliffs, N.J.

(5) 小塚滋久, 中祐一郎, 小林 健二,“交錯する歩行者の衝突回避行動に関する観測と解析”, 日本建築学会学術講演梗概集. E (1988), pp. 563-564.

（6）朝田 伸岡, 大佛 俊泰,“歩行者の回避行動に関する考察”, 日本建築学会 研究報告集 II, No.71 (2001), pp. 105-108.

(7) Rymill, S.J., and Dodgson, N.A., "A Psychologically-based Simulation of Human Behavior", EG UK Theory and Practice of Computer Graphics (2005), pp. 35-42.

（8）依田 光正, 塩田 泰仁,“ 人間同士のすれ違い行動における動作特性および回避行動アルゴリズム: 屋外と屋内での基本実 験結果”，日本機械学会論文集 C 編, Vol.64, No.619 (1998), pp. 959-265.

(9) Antonini, G., Bierlaire, M., and Weber, M., "Discrete Choice Models of Pedestrian Walking Behavior", Transportation Research Part B: Methodological, Vol.40, No.8 (2006), pp. 667-687.

（10）大鋳史男, 小野木 基裕,“ セルオートマトン法による避難流動のシミュレーション”, 日本オペレーションズ・リサーチ学 会和文論文誌, No.51 (2008), pp. 94-111.

(11) Okamoto, T., and Yamada, Y., "Analysis of Human Behavior and Collision Risks at an Indoor Crossroad to Prevent Broadside Collisions", IARP Workshop on the Role of Robotics in Assisted Living (2011), TB1.

(12) 岡本球夫, 山田 陽滋,“相手の駆け引きと情報の不確かさによる行動変化を考慮した出合い頭における歩行者の行動判断 のモデル化”, 第 17 回ロボティクスシンポジア, No.12-2 (2012), pp. 574-579.

(13) Okamoto, T., and Yamada, Y., "Study of Conditions for Safe and Efficient Traffic in an Indoor Blind Corner-based Decision Model with Consideration for Tactics and Information Uncertainty", The 21st IEEE International Symposium on Robot and Human Interactive Communication (2012), pp. 682-688.

(14) Asano, M., Iryo, T., and Kuwahara, M., "A Pedestrian Model Considering Anticipatory Behaviour for Capacity Evaluation", Transportation and Traffic Theory 2009: Golden Jubilee (2009), Springer, New York, pp. 559-581.

(15) Neumann, J.V., Morgenstern, O., Rubinstein, A., and Kuhn, H.W., Theory of Games and Economic Behavior (1944), Princeton University Press.

(16) Nash, J.F., "Equilibrium Points in n-Person Games", Proceedings of the National Academy of Science of USA, Vol.36, No.1 (1950), pp. 48-49.

(17) Roth, A.E., and Erev, I., "Learning in Extensive-Form Games: Experimental Data and Simple Dynamic Models in the Intermediate Term", Games and Economic Behavior, Vol.8, Issue 1(1995), pp. 164-212.

(18) Witten, I.H., "An Adaptive Optimal Controller for Discrete-Time Markov Environments”, Information and Control, Vol.34, No.4 (1977), pp. 286-295.

(19) Sutton, R.S., and Barto, A.G., Reinforcement Learning: An Introduction (1998), A Bradford Book.

(20) Houk, J.C., Adams, J.L., and Barto, A.G., "A Model of How the Basal Ganglia Generate and Use Neural Signals that Predict Reinforcement”, In Houk, J.C., Davis, J.L., and Beiser, D.G.,(Eds.), Models of Information Processing in the Basal Ganglia (1995), The MIT Press, pp. 249-270. 